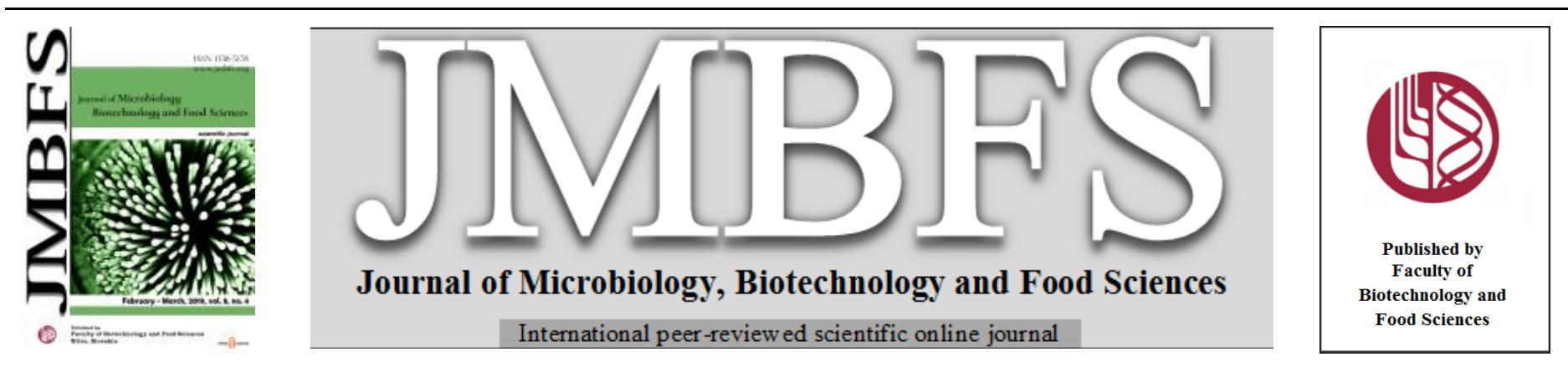

\title{
HALOTOLERANT BACILLUS SP. AS A SOURCE OF ANTIFUNGAL AGENTS AGAINST MAJOR MUSHROOM PATHOGENS
}

\author{
Michelle S. Fernandes ${ }^{l}$ and Savita Kerkar ${ }^{l}$. \\ Address(es): Prof. Savita Kerkar, \\ ${ }^{1}$ Goa University, Department of Biotechnology, Taleigao Plateau, Goa - 403401, India, phone number: +91-(0)832-6519358.
}

*Corresponding author: drsavitakerkar@gmail.com

doi: $10.15414 / j m b f s .2019 .8 .5 .1125-1129$

\section{ARTICLE INFO}

Received 18. 9. 2018

Revised 16. 11. 2018

Accepted 20. 11. 2018

Published 1. 4. 2019

Regular article

open $\partial_{\text {ACCESS }}$

\begin{abstract}
The present study focuses on bioprospecting of halotolerant bacteria from a hypersaline environment for antifungal agents against major mushroom pathogens. A total of 20 morphologically different fungi were isolated from composts and infected fruiting bodies of Agaricus bisporus; belonging to the genera Trichoderma, Penicillium, Aspergillus, Mucor and Rhizopus. In addition, 131 halotolerant bacteria out of 280 exhibited antifungal activity against phytopathogens, Trichoderma sp., and Penicillium sp. The isolates (80) showing maximum and consistent activity were screened against the isolated mushroom pathogens, Trichoderma harzianum MTCC 3178 and Lecanicillium fungicola MTCC 2016. About 33.8\% halotolerant bacteria produced an antifungal metabolite that inhibited the mycelial growth of Trichoderma harzianum MTCC 3178, 20\% inhibited mycelium growth of Lecanicillium fungicola MTCC 2016, 48.8\% other Trichoderma spp., 26.3\% Penicillium spp. and 2.5\% inhibited Aspergillus spp. The bacterial isolate BGUMS93 showed highest broad spectrum activity against these pathogens. Carbohydrate utilization profile, biochemical characteristics and 16S rRNA gene sequencing revealed BGUMS93 as Bacillus sp. (KC991034.1) with 97\% similarity to Bacillus subtilis. BGUMS93 produced extracellular antifungal metabolites in butanol extract showing maximum activity against Trichoderma harzianum MTCC 3178 and in chloroform extract against Lecanicillium fungicola MTCC 2016. Thus, Bacillus spp. from Goa's salterns could be a way to provide natural fungicide as an alternative to synthetic fungicides used in mushroom cultivation.
\end{abstract}

Keywords: Bacillus, antifungal, Trichoderma harzianum, Lecanicillium fungicola, mushroom pathogens, hypersaline

\section{INTRODUCTION}

Agaricus bisporus, known as white button mushroom is one of the most common, globally grown edible mushrooms. The ease of cultivation and its attractive quality and texture along with substantial yield makes it the most cultivated and consumed mushroom. However, they are susceptible to bacterial, fungal and viral diseases (Largeteau and Savoie, 2010). Mushrooms are susceptible to microbial diseases at various stages including compost, casing, spawn run and even mushroom fruiting body. These diseases further propagate through various sources such as air, water, machines and workers causing secondary infections, thereby reducing its yield and marketability. Some of the biggest problems in mushroom cultivation are caused by fungi, namely Lecanicillium fungicola and Trichoderma spp., resulting in severe economic losses.

Lecanicillium fungicola (previously known as Verticillium fungicola), the causal agent of dry bubble disease is the most common fungal disease of Agaricus bisporus (Berendsen et al., 2010). This soil-borne pathogen, at an early stage of mushroom growth results in typical onion shaped mushrooms whereas late infection shows traces of grey mouldy fuzz on the mushrooms. Casing soil serves as the source of the infection, however, other factors also lead to the spread of the disease.

Another destructive disease in mushroom cultivation is the green mould mainly caused by different species of Trichoderma; Trichoderma harzianum causing the major problem (Seaby, 1996; Savoie et al., 2001). Some species of Penicillium and Aspergillus are also found to be causal agents of green mould. Trichoderma spp. cause major losses as they spread quickly and on a massive scale. They occur in all stages of mushroom growth; soil, organic matter and air, being sources of infection. The control of these soil-borne pathogens requires good hygiene and routine fungicide treatment. However, they are difficult to control either because of lack of an effective chemical control or development of fungicide resistance by the pathogen (Gea et al., 2005). Thus, there is a continuous need for an effective and safer fungicide, and microbial sources may play a key role.

Solar salterns are man-made thalassohaline systems with varying salt concentration ranging from 10-350 psu, which are commercially utilized for the production of salt (Kerkar and Bharathi, 2011). Several new compounds from microbes in extreme environments are reported every year, as these are an untapped resource of novel biomolecules such as enzymes, antibiotics and enzyme inhibitors (Zhang et al., 2005; Mondol et al., 2013; Manivasagan et al., 2014; Arasu et al., 2016). Microbial secondary metabolites have been actively studied from marine sources due to its diversity in terms of chemical structures and versatile bioactivity. Thus, the present work was aimed to investigate the potential of hypersaline bacteria from salt pans to suppress mushroom pathogens particularly, Trichoderma harzianum and Lecanicillium fungicola.

\section{MATERIAL AND METHODS}

\section{Bacterial cultures}

Halotolerant bacteria used for the present study were procured from Prof. Savita Kerkar's laboratory collection, which were isolated from the saltern ecosystem of Goa.

\section{Standard fungal cultures}

The standard cultures were procured from Goa University Fungal Culture Collection Centre (Trichoderma sp. GUFCC 5092 and Penicillium sp. GUFCC 396) and Microbial Type Culture Collection, Chandigarh, India (Trichoderma harzianum MTCC 3178 and Lecanicillium fungicola MTCC 2016). The fungi were maintained on potato dextrose agar and stored at $4{ }^{\circ} \mathrm{C}$. All media were procured from HiMedia, India.

\section{Isolation of mushroom pathogens}

Compost (Two samples) and infected fruiting bodies of Agaricus bisporus collected from Zuari Foods \& Farms Pvt. Ltd, Goa, India were examined for mushroom pathogens. Each compost sample $(10 \mathrm{~g})$ was suspended in $90 \mathrm{ml}$ sterile distilled water, serial diluted and plated on Potato Dextrose Agar. The fungal load from the compost sample was determined. Fungi from the fruiting 
body were carefully collected and inoculated on Potato Dextrose Agar under aseptic conditions. The plates were incubated at room temperature until fungal growth was visible and pure cultures were obtained by repetitive streaking. Fung were identified conventionally according to their macroscopic and microscopic features and stored at $4{ }^{\circ} \mathrm{C}$. Fungi with different colony morphology were used further.

\section{Bacterial Culture condition}

The halotolerant bacteria were grown aerobically in Nutrient broth for $96 \mathrm{hr}$ with constant shaking $(120 \mathrm{rpm})$ at $30^{\circ} \mathrm{C} \pm 2$. The supernatant was collected by centrifugation at $10,000 \mathrm{rpm}$ for $10 \mathrm{mins}$ at $4{ }^{\circ} \mathrm{C}$, and the cell-free metabolite was used for the antimicrobial assay.

\section{In-vitro Antagonistic activity}

The antifungal activity of the bacterial cultures was tested against the standard fungi and isolated mushroom pathogens by well diffusion assay as described by Munimbazi and Bullerman (1998) with few modifications. Initially, 280 bacterial isolates were screened for antifungal activity against standard fungi, Trichoderma sp. GUFCC 5092 and Penicillium sp. GUFCC 396. The isolates showing maximum and consistent activity were further screened against standard mushroom pathogens (T. harzianum MTCC 3178 and L. fungicola MTCC 2016) and isolated mushroom pathogens. In brief, spore suspension $(0.1 \mathrm{~mL})$ of respective fungi $\left(10^{7}-10^{10}\right.$ spores $\left./ \mathrm{mL}\right)$ were added to $15 \mathrm{~mL}$ of soft Potato dextrose agar and overlaid on pre-poured Potato dextrose agar. Plates were allowed to dry and wells were bored. The cell-free metabolite $(50 \mu \mathrm{L})$ of each bacterial isolate were added to the wells, and the plates were incubated at $4{ }^{\circ} \mathrm{C}$ for $1 \mathrm{~h}$ for pre-diffusion and then at $30^{\circ} \mathrm{C} \pm 2$ for 3-5 days. The plates were examined for the zone of inhibition.

\section{Bacterial isolate identification}

Phenotypic characteristics were determined as described by Bergey's Manua (Claus and Berkeley 1986). The bacterial isolates were subjected to antibiotic sensitivity testing against 30 different antibiotics using standard antibiotic discs (HiMedia, India). The antibiotic discs were placed on the seeded Muller Hilton agar (HiMedia, India) plates and incubated at $30^{\circ} \mathrm{C}$ for $24-48 \mathrm{~h}$ (Vasanthakumari, 2009). Carbohydrate utilization pattern of the isolate was also studied using Carbohydrate utilization kit and Hi-Bacillus Kit according to manufactures instructions (HiMedia, India). Genomic DNA was isolated using Axygen Bacterial genomic DNA isolation kit and visualized on $0.8 \%$ TBE agarose gel. The $16 \mathrm{~S}$ rRNA gene of each isolate was amplified by PCR, using universal bacterial primers 27F: AGAGTTTGATCCTGGCTCCAG and 1492R TACGGTTACCTTGTTACGACTT (Ballav et al., 2015). The PCR product was visualized on $1 \%$ agarose gel, and the expected $1.5 \mathrm{~kb}$ length band was excised and eluted using GE Health Care, illustra ${ }^{\mathrm{TM}}$ GFX $^{\mathrm{TM}}$ PCR DNA and Gel band purification kit (United States). The obtained sequence was further analyzed by BLAST software. The phylogenetic tree was constructed using MEGA 7.0 (Pennsylvania, U.S.A) by neighbour joining method.

\section{Partial purification of antifungal metabolite of BGUMS93}

A seed culture of BGUMS93 was prepared by inoculating (approximately $3 \times 10^{7}$ cells $/ \mathrm{mL})$ Nutrient broth $(10 \mathrm{~mL})$ and incubating for $24 \mathrm{~h}$ with constant shaking $(120 \mathrm{rpm})$ at $30^{\circ} \mathrm{C} \pm 2$. The seed culture of BGUMS93 was further inoculated in Nutrient broth $(500 \mathrm{~mL})$ and incubated at $28^{\circ} \mathrm{C} \pm 2$ in a rotary shaker at $120 \mathrm{rpm}$ for 4 days. The culture broth was centrifuged at 10,000 rpm for $10 \mathrm{mins}$, and cellfree supernatant was used for sequential solvent extraction, lipopeptide precipitation and diaion resin extraction.

\section{Diaion resin extraction}

The culture filtrate was treated with $2 \mathrm{~g} / 40 \mathrm{~mL}$ Diaion HP-20 resin (Supelco, USA) at $120 \mathrm{rpm}, \mathrm{RT}\left(30^{\circ} \mathrm{C} \pm 0.2\right)$ for 30 mins. The mixture was packed in a column, washed with sterile MilliQ water and eluted with HPLC grade methanol. The methanol extract was collected as Fraction A. To the bacterial pelle obtained, $10 \mathrm{~mL}$ of Chloroform: Methanol (1:1) was added, vortexed and sonicated for $40 \mathrm{~s}$ with pulse and without pulse. After sonicating, it was allowed to stand for $10 \mathrm{mins}$ and centrifuged at $10,000 \mathrm{rpm}$ for $5 \mathrm{mins}$ at $10^{\circ} \mathrm{C}$. The supernatant was collected as fraction B (Banskota et al., 2006). Fraction A \& B were used for testing antifungal activity using methanol and methanol: chloroform as respective controls.

\section{Sequential solvent extraction}

The cell-free culture filtrate was sequentially extracted with five different solvents (Petroleum ether, diethyl ether, ethyl acetate, chloroform and butanol). The extraction was carried out twice with different solvents at 1:1 ratio. All the solvent extracts were dried under vacuum and the resulting extracts were used with the respective solvents as controls (Sihem et al., 2011).

\section{Lipopeptide precipitation}

The cell-free culture broth was precipitated by initially adjusting the $\mathrm{pH}$ to 2.0 with concentrated $\mathrm{HCl}$ and stored overnight at $4^{\circ} \mathrm{C}$. The precipitate was collected by centrifuging at $10,000 \mathrm{rpm}$ for $10 \mathrm{mins}$ and extracted twice with methanol The collected solution was dried under vacuum and this fraction was subsequently used for bioactivity keeping methanol as a control (Kim et al., 2004).

\section{RESULTS AND DISCUSSION}

The total fungal load in the compost sample I was found to be $1.4 \times 10^{5} \mathrm{CFU} / \mathrm{g}$ and sample II was $0.5 \times 10^{6} \mathrm{CFU} / \mathrm{g}$. A total of 9 morphologically different fungi were isolated from the two composts and 11 isolated from infected fruiting bodies and identified microscopically. The fungi isolates belonged to the genera Trichoderma, Penicillium, Aspergillus, Mucor and Rhizopus (Figure 1)

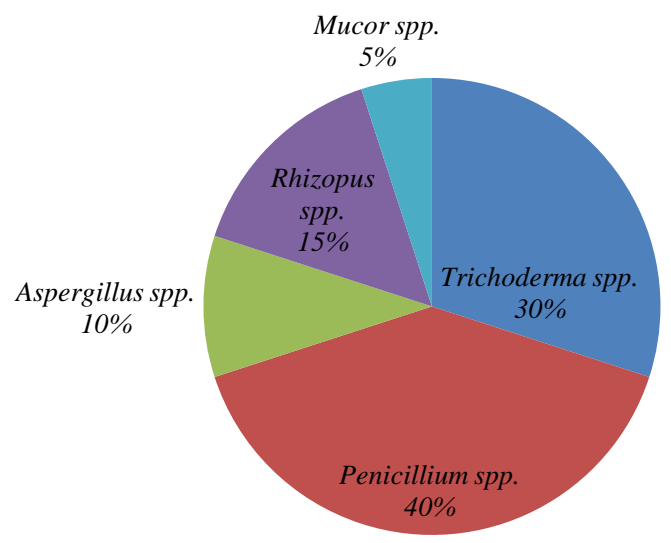

Figure 1 Proportion of Fungi isolated from compost and infected mushroom samples

\section{In-vitro antagonistic activity}

A total of 280 halotolerant bacterial isolates were assayed using cell-free metabolites against Trichoderma sp., and Penicillium sp., from which only 131 isolates exhibited anti-fungal activity. Of the 131 halotolerant cultures, 119 showed activity against Trichoderma sp. and 47 showed activity agains Penicillium $\mathrm{sp}$. However, only $25 \%$ showed maximum activity ( $>20 \mathrm{~mm}$ ) against Trichoderma $\mathrm{sp}$. and $7.2 \%$ showed activity $(>20 \mathrm{~mm})$ against Penicillium $\mathrm{sp}$., and only $5.4 \%$ cultures showed activity $(>20 \mathrm{~mm}$ ) against both the fungal pathogens. Among the (131) bacterial isolates showing antifungal activity during primary screening, 80 isolates showing maximum and consistent activity were screened further against the standard fungal mushroom pathogens. Figure 2 a shows the activity profile against standard mushroom pathogens and Figure $2 b$ against the fungal pathogens isolated by us. About $33.8 \%$ halotolerant bacteria produced an antifungal metabolite that inhibited mycelial growth of Trichoderma harzianum MTCC 3178 and $20.0 \%$ halotolerant bacteria inhibited mycelial growth of Lecanicillium fungicola MTCC 2016. None of the bacterial isolates showed activity against Mucor sp. and Rhizopus spp. In contrast, about $57.5 \%$ bacterial isolates showed no activity against the standard mushroom pathogens and $48.8 \%$ showed no activity against all the isolated mushroom pathogens.
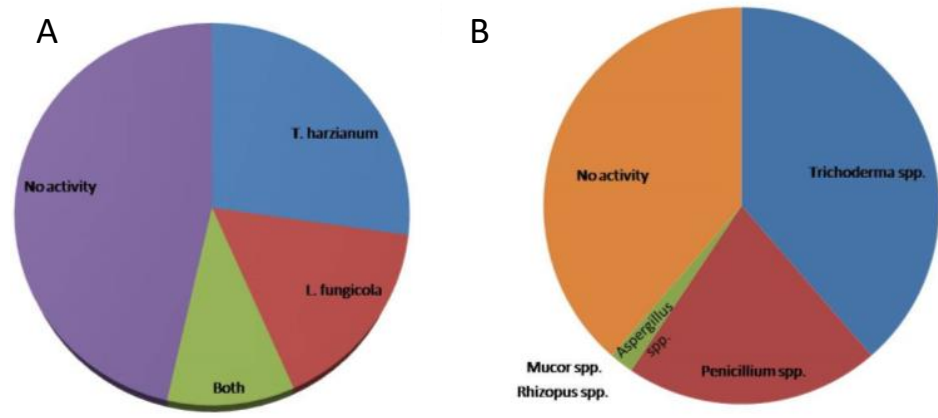

Figure 2 Fungicidal profile of the halotolerant bacterial isolates against (a) standard mushroom pathogens and (b) isolated mushroom pathogens 


\section{Bacterial isolate identification}

The halotolerant bacterial isolate showing highest and broad spectrum anti-fungal activity was BGUMS93. BGUMS93 was found to be Gram positive motile rods with central endospore. In addition, BGUMS93 showed sensitivity to several broad spectrum antibiotics (amikacin, amoxyclav, ampicillin, ampicillin/sulbactam, cephalexin, cephalothin, cephotaxime, chloramphenicol, ciprofloxacin, clindamycin, Co-Trimoxazole, deoxycycline hydrochloride, erythromycin, gentamicin, kanamycin, levofloxacin, lincomycin, nalidixic acid, neomycin, nitrofurantoin, ofloxacin, penicillin-G, streptomycin, tetracycline, vancomycin). However, ceftazidime and cefuroxime stimulated the growth of BGUMS93 and methicillin, oxacillin and tobramycin exhibited mild inhibition. Biochemical characteristics (Table 1) and 16S rRNA gene sequencing revealed BGUMS93 to be Bacillus sp. (KC991034.1) with 97\% similarity to Bacillus subtilis (Figure 3). BGUMS93 could grow in salt concentration of $7 \%$, indicating it is a halotolerant isolate.

\section{Table 1 Biochemical characterization of strain BGUMS93}

Tests

BGUMS93

\begin{tabular}{|c|c|}
\hline Lactose & - \\
\hline Xylose & - \\
\hline Maltose & - \\
\hline Fructose & - \\
\hline Dextrose & $+/-$ \\
\hline Galactose & - \\
\hline Raffinose & - \\
\hline Trehalose & $+/-$ \\
\hline Melibiose & - \\
\hline Sucrose & + \\
\hline L-Arabinose & + \\
\hline Mannose & + \\
\hline Inuline & $+/-$ \\
\hline Sodium gluconate & - \\
\hline Glycerol & $+/-$ \\
\hline Salicin & $+/-$ \\
\hline Dulcitol & - \\
\hline Inositol & $+/-$ \\
\hline Sorbitol & $+/-$ \\
\hline Mannitol & $+/-$ \\
\hline Adonitol & - \\
\hline Arabitol & - \\
\hline Erythritol & - \\
\hline alpha-methyl-D-glucoside & - \\
\hline Rhamnose & $+/-$ \\
\hline Cellobiose & $+/-$ \\
\hline Melezitose & - \\
\hline alpha-methyl-D-mannoside & - \\
\hline Xylitol & - \\
\hline ONPG & - \\
\hline Esculin & + \\
\hline D-Arabinose & - \\
\hline Citrate & - \\
\hline Malonate & - \\
\hline Sorbose & - \\
\hline Arginine & + \\
\hline Voges Proskauer's & - \\
\hline Nitrate Reduction & + \\
\hline Catalase & - \\
\hline Glucose & $+/-$ \\
\hline Oxidase & + \\
\hline Indole & - \\
\hline Starch hydrolysis & + \\
\hline Methyl red test & + \\
\hline Growth at pH 5.7 & + \\
\hline Growth at $7 \% \mathrm{NaCl}$ & + \\
\hline Growth at $55^{\circ} \mathrm{C}$ & + \\
\hline Pigment & - \\
\hline Anaerobic & - \\
\hline
\end{tabular}

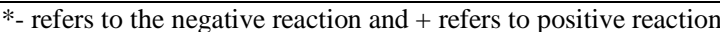

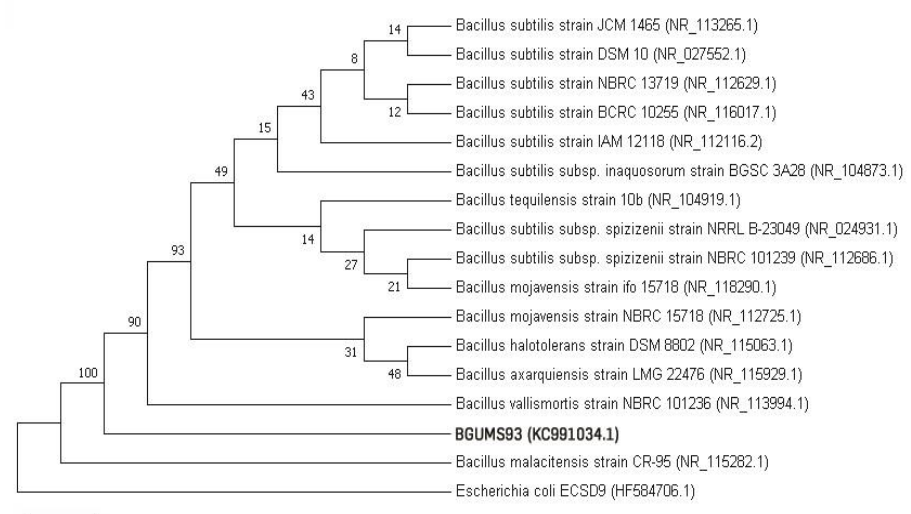

0.050

Figure 3 Phylogenetic tree based on 16S rRNA gene sequence of BGUMS93. $E$ coli ECSD9 was used as an outgroup. The number at the nodes indicate bootstrap values based on 500 replicates.

\section{Antifungal activity of the partially purified metabolite of BGUMS93}

Fraction A showed antifungal activity against T. harizanum and L. fungicola and no activity was observed with Fraction B, suggesting the metabolite was extracellular (Table 2, Figure 4). On sequential solvent extraction, activity was observed with n-butanol extract against both the pathogens, however, a higher activity was observed with chloroform extract against $L$. fungicola. Lipopeptide extract also showed activity against both the pathogens, initially suggesting that the antifungal compound could be a lipopeptide. However, the activity of the lipopeptide extract was lower compared to that of the solvent extract.

Table 2 Antifungal activity of solvent extract of strain BGUMS93

\begin{tabular}{lcc}
\hline Solvent System & \multicolumn{2}{c}{ Zone of Inhibition (mm) } \\
\cline { 2 - 3 } & T. harizanum & L. fungicola \\
\hline Fraction A & $10 \pm 0.00$ & $12 \pm 0.58$ \\
\hline Fraction B & - & - \\
\hline Butanol & $18 \pm 1.15$ & $16 \pm 1.15$ \\
\hline Ethyl acetate & - & $22 \pm 0.58$ \\
\hline Chloroform & - & $25 \pm 1.00$ \\
\hline Diethyl ether & - & - \\
\hline Petroleum ether & - & - \\
\hline Lipopeptide extract & $13 \pm 0.58$ & $15 \pm 1.15$ \\
\hline Cell free supernatant & $15 \pm 0.00$ & $28 \pm 0.58$ \\
\hline *values are in triplicates \pm SD; (-) refers to no activity
\end{tabular}

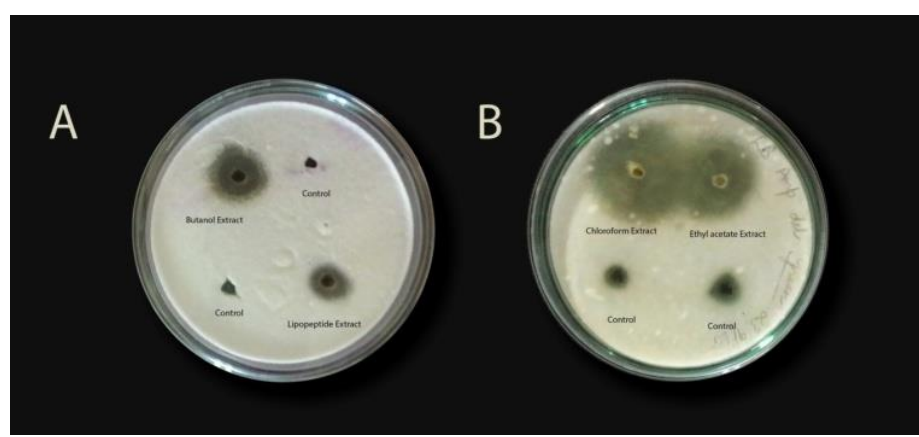

Figure 4 Antagonistic activity profile of extracted metabolite of BGUMS93 against (A) T. harizanum and (B) L. fungicola

Bacillus spp. are known to produce several antifungal compounds including fungycin (Lebbadi et al., 1994), bacillomycin (Xu et al., 2013), iturin (Romero et al., 2007; Gong et al., 2015), which makes it a best fit candidate for biocontrol of several phytopathogens. Apart from this, marine Bacillus have been reported to have antibacterial (El-sersy et al., 2012; Khan et al., 2017; Mayer et al., 2017) and anti-larval activity (Gao et $\boldsymbol{a l}$., 2010). Macrolactins and lipopeptides are also produced widely by marine bacilli showing potent anti-microbia activities (Pabel et al., 2003; Sohn et al., 2008; Lu et al., 2008; Ongena and Jacques, 2008; Jaruchoktaweechai et al., 2000; Mondol et al., 2011; He et al. 2013; Xu et al., 2014; Zhang and Sun, 2018)

Essential oils have been effectively inhibitory to the major mushroom pathogens however, its practical application has yet not been established (Sokovic and Griensven, 2006; Angelini et al., 2008; Tanovic et al., 2009). In contrast, leached spent mushroom compost (SMC) was found to suppress the growth of the mushroom pathogen, L. fungicola, and found effective in increasing the mushroom yield. The disease suppression was attributed to Bacillus spp., isolated from the extracts of leached SMC (Riahi et al., 2012). Several studies have also 
been carried out on the antagonistic effects of Bacillus spp. against Trichoderma harzianum in Pleurotus spp. cultivation (Chittihunsa et al., 2007; VelazquezCedeno et al., 2008; Kim et al., 2008; Shah and Nasreen, 2011). Savoie et al. (2001) suggested that the capacity of $T$. harzianum to colonize mushroom compost was due to its resistance or tolerance to the inhibitory effect of the microorganisms present in the compost. Although Bacillus subtilis is an established biocontrol agent, Zhang $\boldsymbol{e t}$ al. (2009) suggested two different strains of Bacillus subtilis could differ in their antagonistic profile depending on their inter and extracellular proteins.

\section{CONCLUSION}

The increase in the incidence of fungicide resistance among the mushroom fungal pathogens has established the need for an effective and broad spectrum fungicide. BGUMS93 showed broad spectrum antifungal activity to different species of mushroom pathogens. The crude culture supernatant and n-butanol extract showed effective inhibitory activity against $T$. harzianum. In addition, chloroform extract along with the culture supernatant showed strong inhibitory activity against L. fungicola. Thus, making BGUMS93, a Bacillus sp. isolated from a Goan saltern as an ideal biocontrol and effective antimicrobial agent. However, further studies are required to determine the ability of the strain to control these diseases. This is the first report of antifungal activity against $T$. harzianum and $L$. fungicola by a Bacillus sp. isolated from a saltpan and hence, it may provide an alternative resource for biocontrol of mushroom diseases.

Acknowledgments: Authors are grateful to Head of the Department, Department of Biotechnology, Goa University, for providing the facility. Authors also wish to thank Dr. S. Kurade for providing the compost and mushroom samples. This work was supported by the University Grant Commission -Maulana Azad fellowship [MANF-2012-13-CHR-GOA-12673 to M.S.F].

\section{REFERENCES}

Angelini, P., Pagiotti, R., \& Granetti, B. (2008). Effect of antimicrobial activity of Melaleuca alternifolia essential oil on antagonistic potential of Pleurotus species against Trichoderma harzianum in dual culture. World Journal of Microbiology and Biotechnology, 24(2),

197-202. https://dx.doi.org/10.1007/s11274-007-9456-x

Arasu, M. V., Esmail, G. A., \& Al-Dhabi, N. A. (2016). Hypersaline actinomycetes and their biological applications. Actinobacteria Dharumadurai Dhanasekaran, IntechOpen, https://dx.doi.org/10.5772/61065

Ballav, S., Kerkar, S., Thomas, S., \& Augustine, N. (2015). Halophilic and halotolerant actinomycetes from marine saltern of Goa, India producing antibacterial metabolites. Journal of Bioscience and Bioengineering, 119(3), 323330. https://dx.doi.org/10.1016/j.jbiosc.2014.08.017

Banskota, A. H., Mcalpine, J. B., Sorensen, D., Aouidate, M., Piraee, M., Alarco, A., Omura, S., Shiomi, K., Farnet, C. M., \& Zazopoulos, E. (2006). Isolation and identification of three new 5-alkenyl-3,3(2H)-furanones from two Streptomyces species using a genomic screening approach. The Journal of antibiotics, 59(3), 168-176. https://dx.doi.org/10.1038/ja.2006.24

Berendsen, R. L., Baars, J. J. P., Kalkhove, S. I. C., Lugones, L. G, Wosten, H. A. B., \& Bakker, P. A. H. M. (2010) Lecanicillium fungicola: causal agent of dry bubble disease in white-button mushroom. Molecular Plant Pathology, 11(5), 585-595. https://dx.doi.org/10.1111/j.1364-3703.2010.00627.x

Chittihunsa, T., Bangeekhan, E., Wongsamitkul, N. \& Subsomboon, T. (2007) Screening of Bacillus spp. suppressing the infection of Trichoderma sp. in mushroom cultivation. KMITL Science and Technology Journal, 7(1), 19-27.

Claus, D., \& Berkeley, R. C. W. (1986) The genus Bacillus, In: Bergey's Manual of Determinative bacteriology, 2: 1105-1139. Williams \& Wikkins, Baltimore El-Sersy, N. A., Abdelwahab, A. E., Abouelkhiir, S. S., Abou-Zeid, D., \& Sabry, S. A. (2012). Antibacterial and anticancer activity of $\mathcal{E}$-poly-L-lysine (E-PL) produced by a marine Bacillus subtilis sp. Journal of Basic Microbiology, 52(5), 1-10. https://dx.doi.org/10.1002/jobm.201100290

Gao, C., Tian, X., Qi, S., Luo, X., Wang, P., \& Zhang, S. (2010). Antibacterial and antilarval compounds from marine gorgonian associated bacterium Bacillus amyloliquefaciens SCSIO00856. The Journal of Antibiotics, 63, 191-193. https://dx.doi.org/10.1038/ja.2010.7

Gea, F. J., Navarro, M. J., \& Tello, J. C. (2005). Reduced sensitivity of the mushroom pathogen Verticillium fungicola to prochloraz-manganese in vitro. $\begin{array}{llll}\text { Mycological } & \text { Research, } & \text { 109(6), } & 741-\end{array}$ https://doi.org/10.1017/S095375620500242X

Gong, A., Li, H., Yuan, Q., Song, X., Yao, W., He, W., Zang, J., \& Liao, Y. (2015). Antagonistic mechanism of Iturin A and Plipastatin A from Bacillus amyloliquefaciens S76-3 from wheat spikes against Fusarium graminearum PLOS, 10(2), e0116871. https://dx.doi.org/10.1371/journal.pone.0116871

He, S., Wang, H., Yan, X., Zhu, P., Chen, J., \& Yang, R. (2013). Preparative isolation and purification of macrolactin antibiotic from marine bacterium Bacillus amyloliquefaciens using high speed counter current chromatography in stepwise elution method. Journal of Chromatography A, 1272, 15-19. http://dx.doi.org/10.1016/j.chroma.2012.11.029
Jaruchoktaweechai, C., Suwanborirux, K., Tanasuoawatt, S., Kittakoop, P., \& Menasveta, P. (2000). New Macrolactins from Marine Bacillus sp. Sc026. Journal of Natural Products, 63(7), 984-986. http://dx.doi.org/10.1021/np990605c

Kerkar, S., \& Bharathi, P. A. L. (2011). G model revisited: Seasonal changes in the kinetics of sulphate reducing activity in the salterns of Ribander, Goa, India. Geomicrobiology Journal, 28(3),

https://dx.doi.org/10.1080/01490451003780921

Khan, M. N., Lin, H., Li, M., Wang, J., Mirani, Z. A., Khan, S. I., Buzdar, M. A., Ali, I., Jamil, K. (2017). Identification and growth optimization of a marine Bacillus DK1-SA11 having potential of producing broad spectrum antimicrobial compounds. Pakistan Journal of Pharmaceutical Sciences, 30(3), 839-853.

Kim, P. I., Bai, H., Bai, D., Chae, H., Chung, S., Kim, Y., Park, R., \& Chi, Y. T. (2004). Purification and characterisation of a lipopeptide produced by Bacillus thuringiensis CMB26. Journal of Applied Microbiology, 97(5), 942-949. https://dx.doi.org/10.1111/j.1365-2672.2004.02356.x

Kim, W. G., Weon, H. Y., Seok, S. J., \& Lee, K. H. (2008). In vitro antagonistic characteristic characteristics of Bacilli isolates against Trichoderma spp. and three species of mushrooms. Mycobiology, 34(4), 266-269. https://dx.doi.org/10.4489/MYCO.2008.36.4.266

Largeteau, M. L., \& Savoie, J-M. (2010). Microbially induced diseases of Agaricus bisporus: biochemical mechanisms and impact on commercial mushroom production. Applied Microbiology and Biotechnology, 86(1), 63-73. https://dx.doi.org/10.1007/s00253-010-2445-2

Lebbadi, M., Galvez, A., Maqueda, M., Martinez-Bueno, M., \& Valdivia, E. (1994). Fungicin M-4: a narrow spectrum peptide antibiotic from Bacillus licheniformis M-4. Journal of Applied Bacteriology, 77(1), 49-53.

Lu, X., Xu, Q., Liu, X., Cao, X., Ni, K., \& Jiao, B. (2008). Marine drugs

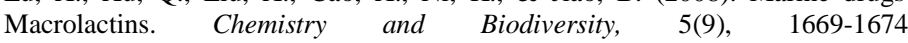
https://dx.doi.org/10.1002/cbdv.200890155

Manivasagan, P., Venkatesan, J., Sivakumar, K., \& Kim, S. (2014) Pharmaceutically active secondary metabolites of marine actinobacteria. Microbiological Research, $\quad$ 169(4), 262-278. https://dx.doi.org/10.1016/j.micres.2013.07.014

Mayer, A. M. S., Rodriguez, A. D., Taglialtela-Scafati, O., \& Fusetani, N. (2017). Marine Pharmacology in 2012-2013: Marine compounds with antibacterial, antidiabetic, antifungal, anti-inflammatory, antiprotozoal, antituberculosis and antiviral activities; affecting the immune and nervous systems, and other miscellaneous mechanisms of action. Marine drugs, 15(9), 273-334. https://dx.doi.org/10.3390/md150902733

Mondol, M. A. M., Kim, J. H., Lee, H., Lee, Y., \& Shin, H. J. (2011) Macrolactin W, a new antibacterial macrolide from a marine Bacillus sp.. Bioorganic and Medicinal Chemistry $\quad$ Letter, 21(12), 3832-3835. https://dx.doi.org/10.1016/j.bmcl.2010.12.050

Mondol, M. A. M., Shin, H. J., \& Islam, M. T. (2013). Diversity of secondary metabolites from marine Bacillus species: Chemistry and biological activity. Marine Drugs, 11(8), 2846-2872. https://dx.doi.org/10.3390/md11082846

Munimbazi, C., \& Bullerman, L. B. (1998). Isolation and partial characterization of antifungal metabolites of Bacillus pumilus. Journal of applied Microbiology, 84(6), 959-968

Ongena, M., \& Jacques, P. (2008). Bacillus lipopeptides: Versatile weapons for plant disease biocontrol. Trends in Microbiology, 16(3), 115-125. https://dx.doi.org/10.1016/j.tim.2007.12.009

Pabel, C., Vater, J., Wilde, C., Franke, P., Hofemeister, J., Adler, B. Bringmann, G., Hacker, J., \& Hentschel, U. (2003). Antimicrobial activities and matrix-assisted laser desorption /ionisation mass spectrometry of Bacillus isolates from the marine sponge Aplysine aerophoba. Marine Biotechnology, 5, 424-434. https://dx.doi.org/10.1007/s10126-002-0088-8 Riahi, H., Hashemi, M., \& Sharifi, K. (2012). The effect of spent mushroom compost on Lecanicillium fungicola in vivo and in vitro. Archives of Phytopathology and Plant Protection, 45(17), 2120-2131. https://dx.doi.org/10.1080/03235408.2012.721684

Romero, D., Vicente, A., Rakotoaly, R., Dufour, S. E., Veening, J., Arrebola, E., Cazorla, F. M., Kuipers, O. P., Paquot, M., \& Perez-Garcia, A. (2007). The Iturin and fengycin families of lipopeptides are key factors in antagonism of Bacillus subtilis towards Podosphaera fusca. Molecular Plant-Microbe Interactions, 20(4), 430-440.

Savoie, J., Iapicco, R., \& Largeteau-Mamoun, M. L. (2001). Factors influencing the competitive saprophytic ability of Trichoderma harzianum Th2 in mushroom (Agaricus bisporus) compost. Mycological Research, 105(11), 1348-1356. https://dx.doi.org/10.1017/S0953756201004993

Seaby, D. A. (1996). Investigation of the epidermiology of green mould of mushroom (Agaricus bisporus) compost caused by Trichoderma harzianum. Plant Pathology, 45(5), 913-923. https://dx.doi.org/10.1111/j.13653059.1996.tb02902.x

Shah, S., \& Nasreen, S. (2011). Evaluation of bioagents against the infection of green mould (Trichoderma spp.) in Pleurotus sajor-caju cultivation. International Journal of Plant Pathology, 2(2), 81-88 https://dx.doi.org/10.3923/ijpp.2011 
Sihem, B. M., Rafik, E., Florence, M., Mohamed, C., \& Ahmed, L. (2011) Identification and partial characterization of antifungal and antibacterial activities of two Bacillus sp. strains isolated from salt soil in Tunisia. African Journal of Microbiological Research, 5(13), $1599-1608$ http://dx.doi.org/10.5897/AJMR11.073

Sohn, M., Zheng, C., \& Kim, W. (2008). Macrolactin S, a new antibacterial agent with Fab G-inhibitory activity from Bacillus sp. AT28. The Journal of Antibiotics, 61(11), 687-691. https://dx.doi.org/10.1038/ja.2008.98

Sokovic, M. \& Griensven, L. J. L. D. (2006) Antimicrobial activity of essential oils and their components against the three major pathogens of the cultivated button mushrooms, Agaricus bisporus. European Journal of Plant Pathology, 116(3), 211-224. https://dx.doi.org/10.1007/s10658-006-9053-0

Tanovic, B., Protocnik, I, Delibasic, G., Ristic, M., Kostic, M., \& Markovic, M. (2009). In vitro effect of essential oils from aromatic and medicinal plants on mushroom pathogens: Verticillium fungicola var fungicola, Mycogne perniciosa and Cladobotryum sp. Archives of Biological Sciences Belgrade, 61(2), 231-237. Vasanthakumari, R. (2009) Practical Microbiology. New Delhi: BI Publication.

Velazquez-Cedeno, M., Farnet, A. M., Mata, G., \& Savoie, J. (2008). Role of Bacillus spp. in antagonism between Pleurotus ostreatus and Trichoderma harzianum in heat-treated wheat-straw substrates. Bioresource Technology, 99, 6966-6973. https://dx.doi.org/10.1016/j.biortech.2008.01.022

Xu, H., Rong, Y., Zhao, M., Song, B., \& Chi, Z. (2014). Antibacterial activity of the lipopeptides produced by Bacillus amyloliquefaciens M1 against multi-drug resistant Vibrio spp. isolated from diseased marine animals. Applied Microbiology and $\quad$ Biotechnology, 98, 127-136. https://dx.doi.org/10.1007/s00253-013-5291-1

Xu, Z., Shao, J., Li, B., Yan, X., Shen, Q., \& Zhang, R. (2013). Contribution of Bacillomycin D in Bacillus amyloliquefaciens SQR9 to antifungal activity and biofilm formation. Applied and Environmental Microbiology, 79(3), 808-815 http://dx.doi.org/10.1128 /AEM.02645-12

Zhang, C. X., Zhao, X., Han, F., Yang, M. F., Chen, H., Chida, T., \& Shen, S. H. (2009). Comparative proteome analysis of two antagonist Bacillus subtilis strains. Journal of Microbiology and Biotechnology, 19(4), 351-357. https://dx.doi.org/10.4014/jmb.0805.346

Zhang, L., \& Sun, C. (2018). Fengycins, cyclic lipopeptides from marine Bacillus subtilis strains, kill the plant-pathogenic fungus Magnaporthe grisea by inducing reactive oxygen species production and chromatin condensation. Applied and
Environmental
Microbiology,
84(18),
$1-17$

https://dx.doi.org/10.1128/AEM.00445-18

Zhang, L., An, R., Wang, J., Sun, N., Zhang, S., Hu, J., \& Kuai, J. (2005).

Exploring novel bioactive compounds from marine microbes. Current Opinion in Microbiology, 8(3), 276-281. https://dx.doi.org/10.1016/j.mib.2005.04.008 